DOI https://doi.org/10.51989/NUL.2021.5.24

\title{
РЕЦЕНЗІЯ НА МОНОГРАФІЮ «РЕКОДИФІКАЦІЯ ЦИВІЛЬНОГО ЗАКОНОДАВСТВА УКРАЇНИ: ВИКЛИКИ ЧАСУ ${ }^{1}$
}

\section{Дзера Олександр Васильович,}

доктор юридичних наук, професор, заслужений юрист України, член-кореспондент Національної академії правових наук України, професор кафедри цивільного права

Київського національного університету імені Тараса Шевченка

\section{Коссак Володимир Михайлович,}

доктор юридичних наук, професор, заслужений юрист України,

завідувач кафедри цивільного права та процесу

Львівського національного університету імені Івана Франка

\section{Яроцький Віталій Леонідович,}

доктор юридичних наук, професор, заслужений діяч науки і техніки, член-кореспондент Національної академії правових наук України, завідувач кафедри цивільного права № 2

Національного юридичного університету імені Ярослава Мудрого

Україна як суверенна і незалежна, демократична, соціальна, правова держава має базуватися на розвинутому громадянському суспільстві. Надійним фундаментом розбудови громадянського суспільства $\epsilon$ налагоджений регуляторний механізм приватноправового законодавства, ідеологічну роль у якому відіграє Цивільний кодекс України.

Як відомо, розробка нового Цивільного кодексу України не була простою. До широкого публічного діалогу з обговорення тексту проєкту кодексу були долучені усі зацікавлені особи. Обговорювалися актуальні питання правового регулювання майнових та особистих немайнових відносин, зокрема визначення природи та галузевої приналежності корпоративних правовідносин, питання щодо співвідношення цивільного права з іншими галузями приватного права: сімейним правом, міжнародним приватним правом та ін. Результатом дискусії вчених-цивілістів та практиків стало повноцінне фахове обґрунтування формулювання правових норм та напрацювання єдиного концептуального бачення унормування приватноправових відносин. Відтак прийнятий 16 січня 2003 року Цивільний кодекс України став стрижневим актом цивільного законодавства, своєрідною «економічною Конституцією».

Інтеграція України до європейського простору, модернізація економічних відносин, глобалізаційні процеси, розвиток технологій, цивільного обороту та поява в ньому нових об'єктів, переосмислення фундаментальних підходів до інституту цивільно-правової відповідальності тощо ставлять нові виклики перед сучасною державою, що потребують відповідної реакції в тому числі у сфері нормопроєктування. Зважаючи на необхідність подальших приватноправових реформ, Уряд України прийняв відповідні акти щодо рекодифікації цивільного законодавства України та утворив Робочу групу щодо рекодифікації (оновлення) цивільного законодавства України. Пізніше розпорядженням Голови Верховної Ради України від 28.07.2020 № 260 створено Робочу групу з підготовки законопроекту з рекодифікації (оновлення) цивільного законодавства України. Членами Робочої групи у 2020 році підготовлено Концепцію оновлення Цивільного кодексу України, у якій представлено основні вектори вдосконалення нормативного масиву ЦК України.

Розробники Концепції виходили з того, що системних змін і суттєвих структурних новацій потребують усі книги чинного Цивільного кодексу України. Тому була розпочата

\footnotetext{
Рекодифікація цивільного законодавства України: виклики часу : монографія / за заг. ред. Н. С. Кузнєцової. Одеса : Видавничий дім «Гельветика», 2021.
} 
складна робота з рекодифікації цивільного законодавства, яка потребує системного та відкритого обговорення концепцій і текстів фундаментальних проєктів щодо внесення змін до Цивільного кодексу України. Власне монографія «Рекодифікація цивільного законодавства України: виклики часу» і $\epsilon$ тією колективною науковою працею, у якій автори Концепції оновлення Цивільного кодексу України, члени Робочої групи з підготовки законопроекту з рекодифікації (оновлення) цивільного законодавства України, провідні українські цивілісти обговорюють теоретико-методологічні засади оновлення цивільного законодавства та вносять пропозиції щодо вдосконалення та гармонізації правового регулювання приватних відносин.

У Передмові до рецензованої праці Голова Верховної Ради України Руслан Стефанчук та віцепрезидент Національної академії правових наук України Наталія Кузнєцова відзначають, що інтеграція України до європейського простору, інтенсивні глобалізаційні процеси, розробка в Європі і загалом у світі численних рекомендаційних актів гармонізаційного спрямування ставлять нові виклики перед українською державою у сфері нормопроєктування і спонукають до врахування європейських тенденцій у процесі вдосконалення приватноправового законодавства². Саме в контексті врахування європейських тенденцій у процесі вдосконалення приватноправового законодавства розглядаються питання оновлення цивільного законодавства в підрозділах монографії, зокрема: 1.1. «Сучасні тенденції розвитку приватного права як регулятора суспільних відносин», підготовленого д.ю.н., професором Н. С. Кузнєцовою; 1.2. «Основні чинники і передумови оновлення цивільного законодавства України, напрями рекодифікації» за авторством д.ю.н., професора А. С. Довгерта; 1.3. «Гармонізація сучасного приватного права: виклики часу», автором якого є д.ю.н., професор І. А. Діковська; 4.1. «Загальні підходи і принципи регулювання речових правовідносин в умовах ре кодифікації та європеїзації» - автор д.ю.н., професор Р. А. Майданик; 5.2. «Імплементація гармонізованих підходів у регулюванні договірних відносин у процесі рекодифікації ЦК України», підготовленого д.ю.н., професором А. Б. Гриняком тощо.

Окрема увага в монографії присвячена обґрунтуванню доцільності визнання таким, що втратив чинність, Господарського кодексу України та закріплення на законодавчому рівні керівної ролі ЦК України в регулюванні приватноправових відносин. Цілком слушно в підрозділі 1.4. «Загальні положення ЦК України: сталі принципи і новітні тенденції» д.ю.н., професор О. О. Кот зазначає: «Книга перша ЦК (а за нею - і інші книги оновленого ЦК України, що розвиватимуть ії̈ положення) має створювати максимально комфортні умови для розвитку громадянського суспільства України, адже загальні підходи та гарантії здійснення та захисту прав - особистих прав, права власності, інтелектуальних прав тощо - мають назавжди закріпити вектор розвитку України як європейської держави, без жодної можливості повернення до адміністративно-планової неконкуренційної економіки, закріпити створений Цивільним кодексом у 2003 році базис для розбудови зрозумілих для інвесторів умов ведення бізнесу в Україні, забезпечити можливість комфортного здійснення підприємницької діяльності для малого та середнього бізнесу, які мають стати рушійною силою економічного зростання української держави в найближчому майбутньому»³.

Зміна суспільної свідомості та значення особистих немайнових відносин спонукає до зміни загального вектора спрямування національного галузевого законодавства відповідно до визначеної ієрархії соціальних цінностей, на вершині якої людина та внутрішні (духовні) блага. У цьому контексті беззаперечної уваги заслуговує Розділ 2 «Регулювання немайнових відносин: еволюція поглядів та вдосконалення регуляторних механізмів», у якому досліджуються особисті немайнові відносини в предметі цивільного права, інформація як об'єкт приватноправового регулювання, розвиток механізмів регулювання та захисту особистих немайнових відносин.

\footnotetext{
2 Рекодифікація цивільного законодавства України: виклики часу : монографія / за заг. ред. Н. С. Кузнєцової. Одеса : Видавничий дім «Гельветика», 2021. С. 7.

3 Рекодифікація цивільного законодавства України: виклики часу : монографія / за заг. ред. Н. С. Кузнєцової. Одеса : Видавничий дім «Гельветика», 2021. С. 71, 90.
} 
Важливим із точки зору наукового обґрунтування необхідності оновлення цивільного законодавства $є$ досвід правозастосування, особливо правові позиції вищих судових інстанцій. Тому інтерес викликає підрозділ 5.3. «Вдосконалення механізмів регулювання зобов'язальних відносин і судова практика» за авторством судді Верховного Суду, д.ю.н., професора С. О. Погрібного.

Вагоме наукове та прикладне значення для вдосконалення приватноправового законодавства мають й інші розділи та підрозділи монографії «Рекодифікація цивільного законодавства України: виклики часу».

Монографією охоплено теоретико-методологічні засади вдосконалення цивільного законодавства, а також наводиться обґрунтування та надаються пропозиції щодо оновлення більшості сфер, що охоплюються приватноправовим регулюванням: немайнових відносин, відносин інтелектуальної власності, речових відносин, зобов'язальних, корпоративних, сімейних відносин. Додатково аналізуються основні напрями оновлення окремих інститутів загальної частини Цивільного кодексу України, зокрема: інституту юридичної особи, інституту правочину, застосування способів захисту цивільних прав, прямо не передбачених законом або договором.

Велике практичне значення має розміщення в додатку до монографії тексту Концепції оновлення Цивільного кодексу України з коментарями ії̈ авторів. Це дає змогу більш широкому колу зацікавлених осіб не тільки ознайомитися із представленими у Концепції напрямами системних змін та структурних новації, що запропоновані членами Робочої групи, а й зрозуміти практичну потребу та побачити можливий результат таких змін та новацій.

Таким чином, рецензоване монографічне дослідження $є$ своєчасним та необхідним. Реалізація окреслених у роботі напрямів та втілення представлених пропозицій дасть змогу вдосконалити різні за своїм обсягом і значенням правові масиви та конструкції, що, у свою чергу, сприятиме формуванню реальної й ефективної ринкової економіки та євроінтеграційній спрямованості всіх компонентів суспільства.

Вважаємо, що монографія $\epsilon$ вагомою науковою працею, що містить обґрунтовані пропозиції щодо вдосконалення і гармонізації правового регулювання приватних відносин, а також створює широкий простір для наукових дискусій у професійному середовищі, тим самим виконуючи своє основне призначення. 